PNNL-11041

UC-810

Project Technical Information

PECEIVED

HAR 221996

Frit Specification Development:

Letter Report

OSTI
P. A. Smith
P. R. Hrma
J. D. Vienna
P. T. Fini

March 1996

Prepared for the U.S. Department of Energy under Contract DE-AC06-76RLO 1830

Pacific Northwest National Laboratory Operated for the U.S. Department of Energy by Battelle Memorial Institute
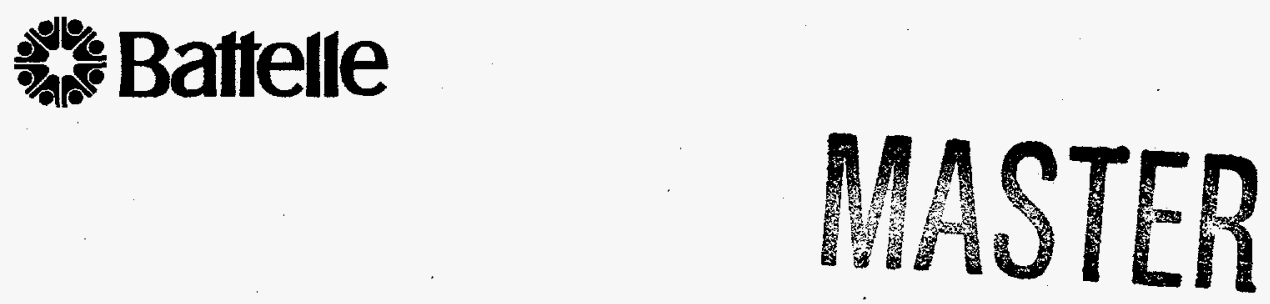

DISTRIBUTION OF THIS DOCUMENT IS UNLMITED BS 
PNNL-11041

UC-810

Project Technical Information

\title{
Frit Specification Development: Letter Report
}

\author{
P. A. Smith \\ P. R. Hrma \\ J. D. Vienna \\ P. T. Fini
}

March 1996

Prepared for

the U.S. Department of Energy

under Contract DE-AC06-76RLO 1830

Pacific Northwest National Laboratory

Richland, Washington 99352

Reprint of historical document PHTD-C93-03.01H, dated October 1993. Data, formatting, and other conventions reflect standards at the original date of printing. Technical peer teviews and editorial reviews may not have been performed. 


\title{
DISCLAI.SAER
}

This report was prepared as an account of work sponscred by an agency of the United Staies Covernment. Neither the Lnited Siates Covernment nor any agency thereof, nor Bantelle Nemorial Instituie, nor any of their employes, makes any warranty, express or implied, or assumes any legalliability or responsibility for the accuracy, completeness, or.usefulness of any information, apparafus, product, or process disclosed, or represents that its use would not iniringe privately owned rights. Reference heiein io any specinic commercial product, process, or service by trade name, ia demark, manufactuier, or othenwise d'ues not necessarily constivute or imply its endorsement, recommendation, or favoring by the United States Government or any agency thereof, or Banelle Memorial Instituie. The views and opinions of authors expressed herein do not necessarily state or reflect those of the United States Covernment or any agency thereof.

\author{
PACIFIC NORTHWEST NATIONAL LABORATORY \\ operaied by \\ BATTELLE \\ for the \\ UNITED STATES DEPARTMENT OF ENERCY \\ under Contract DE-ACO6-76RLO 1830
}

Printed in the United States of America

Available to DOE and DOE contractors from the

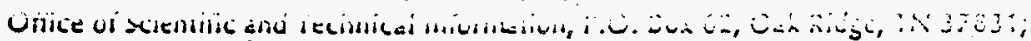
prices, available from (615) 576-8401.

Available to the public from the National Technical infosmation Service, U.S. Depariment of Commerce, 5285 Port Royal Rd., Springiteld, VA 22161 


\section{CONTENTS}

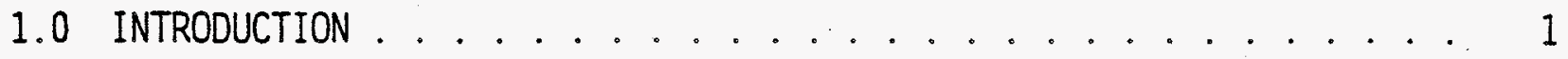

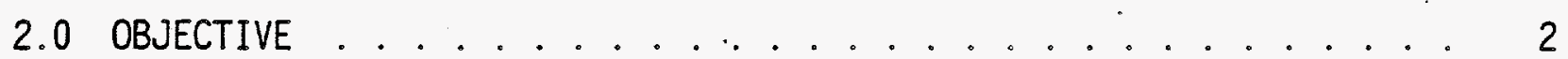

3.0 CONCLUSIONS AND RECOMMENDATIONS .............. 2

4.0 VITRIFICATION AND GLASS ACCEPTABILITY . . . . . . . . . 4

5.0 REQUIREMENTS FOR THE CURRENT HWVP DESIGN ............ . . 13

5.1 STORAGE/HANDLING ...................... 14

5.2 FRIT SLURRY RHEOLOGY REQUIREMENTS . . . . . . . . . 15

5.3 FRIT SLURRY ABRASIVITY REQUIREMENTS . . . . . . . . . 16

5.4 MELTER FEED REQUIREMENTS . . . . . . . . . . . . . 17

5.5 FRIT COOLING . . . . . . . . . . . . . . . 23

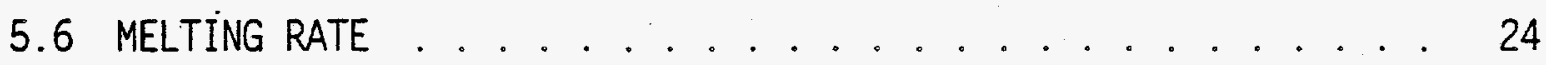

5.7 HIERARCHY ........................... 24

6.0 SCHEDULE AND COST ........................... 25

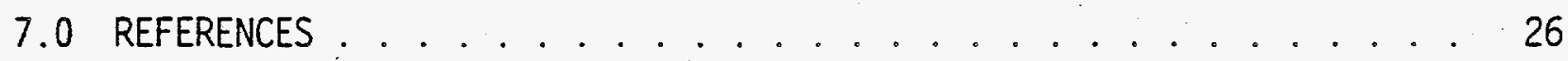




\section{FIGURES}

Figure

Number

1 Volume Fraction of Crystalline Phases vs. Waste Loading

2a Molar Fraction of Frit Component in Solution After 7-Day PCT

2b Normalized Boron Release from Frit After 7-Day PCT . . . .

3

pH Versus Time for $500 \mathrm{~g}$ TO/L NCAW Melter Feed . . . . . . 22
Title

Page

Number 


\section{$\underline{\text { TABLES }}$}

Table

Number

Title

Page

Number

1 Frit Specification Summary .............. 5

2 Upper and Lower Limits on Mass Fractions of Glass Components ............... 6

3 Upper Limits on Critical Solubility Components . . . . . . 7

4 Minimum and Maximum Glass Property Values . . . . . . . . 8

$5 \quad$ Glass and Frit Compositions of Increased Waste Loading Glasses . . . . . . . . . . . . . . 11

6 Frit Compositions ............... 19

7 MCC-1 Results for HW39. Fy91 and 202 Frits ......... 19

8 Percent Cation Leached from Frit After Four Weeks of Aging 


\subsection{INTRODUCTION}

To specify frit for the Hanford Waste Vitrification Plant (HWVP), the relevant requirements and characterization need to be established. The properties and applicable testing will be incorporated into a specification.

Several areas have been identified that require consideration in a frit specification:

- glass processability and acceptability

- frit storage and handling

- frit slurry rheology

- melter feed rheology

- canister decontamination

- pumping equipment/pipe erosion

- frit cooling rate

- glass melting rate

The listed areas are influenced primarily by frit composition, temperature history, particle morphology, particle size, size distribution, and properties that depend on the primary variables such as hardness and frit density. Frit development proceeds in two steps: the first focuses on the waste glass, and the second on the pre-melt (including cold cap) processing.

The first step in frit specification emphasizes the glass composition as a factor determining acceptability for isolation in a geologic repository and glass processability in the melter. The requirements imposed by glass acceptability and processability are the most limiting for frit specification. Frit composition is determined by the desired waste glass composition, waste type and loading. Thus, maintaining processability and acceptability requirements and increasing waste loading limits the degrees of freedom for frit composition selection.

The second step of the frit development focuses on evaluation of the processing before the waste feed is converted to melt. These areas include frit storage and handling, canister decontamination (if performed by frit 
slurry blasting), pipe and pumping equipment erosion. frit slurry rheology. melter feed rheology, frit cooling rate and melting rate. Including the melting rate provides a consideration for the fusion of the frit with the waste. This subject is the focus of a different report (Kim 1993). The majority of the frit characteristics related to handling and processability depend on frit particle size and size distribution, particle shape, hardness and density. Composition determines frit interaction with the aqueous medium which strongly influences rheology and storage requirements.

The frit specifications are listed in Table 1 . The specifications. and their hierarchy are described in subsequent text.

\subsection{OBJECTIVE}

This study was performed to recommend frit specification requirements and the associated testing needs.

\subsection{CONCLUSIONS AND RECOMMENDATIONS}

- The preceding specifications and methodology should be adopted for HWVP frit specification. These specifications should be considered for future frit procurement. These specifications must be revisited when process flowsheet revisions are made.

- Several areas of the specification are 111 -defined because the performance criteria are not fully defined, and hence, the frit requirements have not been clearly stated. These areas.need to be addressed and include:

frit slurry rheology

melter feed rheology

frit slurry abrasivity

frit cooling rate

melting rate 
- The required frit slurry performance is attained by specifying the weight percent solids and the formic acid concentration of the suspension. Currently, this is not sufficient for HWVP processing. As fluid mechanical requirements become more defined, this area will require rheological testing.

- Canister decontamination and pumping/pipe erosion require frit slurry abrasivity. Canister decontamination is facilitated by a highly abrasive slurry. Erosion is avoided by low abrasivity. The requirement of the frit slurry abrasivity must be reexamined before a realistic specification can be made. This could lead to added work.

- The degree of frit influence on the melting rate has not been defined. A melting rate investigation must be executed to include it in a frit specification (see the results of the melting rate study (Kim 1993). However, the FY 91 frit has been linked to slow melting rate. This behavior must be investigated so that frit is specified based on defined process requirements.

The following recommendations are included to supplement the frit specification. These recommendations, if followed. would not result in direct changes to the specifications. The recommendations are essentially related development work that will result in cost savings in frit development. improve flexibility in melter design and show mitigation techniques which would ensure plant operability and improve safety margins.

- Melter feed rheology is the area where the perceived frit performance has been less than adequate. To require changes in frit composition based on the melter feed rheology experience would be near-sighted. Options for melter feed rheology are required. These options that should be explored include: chelating agents which would interact with the frit leachate and prevent gelling: capping agents to prevent condensation reactions that lead to ge 1 networks: and surfactants that would prevent frit leaching.

- The range of acceptable frit compositions for aqueous environments has not been established. A property composition model for frit composition should be developed. The influence of phase separation and cooing rate can also be captured as part of this investigation. The frit-water interaction can be measured by the Product Consistency Test (PCT). This approach will provide the required information for frit processing. The result would be a phase diagram based on frit durability of likely frit compositions. In addition, the data will be useful regardless of changes in the HWVP process flowsheet and/or melter design. 


\subsection{VITRIFICATION AND GLASS ACCEPTABILITY}

There are several key frit criteria that must be considered to insure the success of the HWVP. Waste loading of the glass product is a required process specification since it determines the quantity of waste glass produced and is a major factor in the HWVP operating cost. The waste loading will be optimized and defined by specifying the waste glass composition and the frit composition.

Waste loading is the mass fraction of waste in the waste glass. To maximize the production efficiency and lower the operating costs of the HWVP. the optimization of waste loading is tantamount. To obtain optimal waste loading (OWL), a computer program has been developed that considers the glass composition-property models and subsequently calculates a frit composition. The calculated frit composition optimizes waste loading.

The OWL algorithm is based on the mass fractions of the individual components in the waste glass. The waste glass is composed of frit. waste and recycle. The mass fraction of each component in the glass, $g_{i}$, is defined in terms of its mass fractions in the waste, $w_{i}$, recycle, $r_{i}$ and the frit. $f_{i}$, and the fractions of the waste $(W)$ and recycle $(R)$ in the glass:

$$
g_{i}=w_{i} W+r_{i} R+f_{i}(1-W-R)
$$

The mass fractions of the components sum to one for the frit, recycle, waste and glass:

$$
\sum_{i=1}^{10} f_{i}=\sum_{i=1}^{10} w_{i}=\sum_{i=1}^{10} r_{i}=\sum_{i=1}^{10} g_{i}=1
$$

The summation is for the 10 components considered by the glass composition property models (i.e., the 9 major components plus "others" are treated as individual components).

The validity of the property models is restricted to the range of glass compositions shown in Table 2 (Hrma and Piepel 1992). This range defines the 
TABLE 1. Frit Specification Summary

o

\begin{tabular}{|c|c|c|c|c|}
\hline Specification & Test Measurement & Application & Test Conditions & $\begin{array}{c}\text { Acceptance } \\
\text { Criteria } \\
\end{array}$ \\
\hline \multirow[t]{3}{*}{$\begin{array}{l}\text { Glass } \\
\text { processabil- } \\
\text { ity and } \\
\text { acceptability }\end{array}$} & $\begin{array}{l}\text { Calculate optimal frit composition based } \\
\text { on: 1) cvs constraints. 2) durability. } \\
\text { electrical conductivity. and viscosity }\end{array}$ & \multirow{3}{*}{$\begin{array}{l}\text { Maximize waste loading } \\
\text { Melting ease } \\
\text { Ourability glass } \\
\text { Processable glass }\end{array}$} & Computer calculation & \multirow[t]{3}{*}{$\begin{array}{l}\text { CVS criteria } \\
\text { see Tables } 2.3 \\
\text { and } 4\end{array}$} \\
\hline & $\begin{array}{l}\text { Examine crystall inity: } \\
\text { 1) Phase equil ibrium software } \\
\text { 2) Optical microscopy } \\
\text { 3) SEM/EDS } \\
\text { 4) X-ray diffraction }\end{array}$ & & $\begin{array}{l}\text { Computer calculation. Quenched } \\
\text { glass. Canister Centerline } \\
\text { Cooled (CCC) glass. }\end{array}$ & \\
\hline & Examine durability with PCT & & Quenched glass. CCC samples & \\
\hline \multirow{2}{*}{$\begin{array}{l}\text { Storage/handl } \\
\text { ing } \\
\text { properties }\end{array}$} & Flow rate & Required for frit transport & \multirow{2}{*}{$\begin{array}{l}\text { As received } \\
\text { As a function of time } \\
\text { temperature and humidity }\end{array}$} & \multirow{2}{*}{$\begin{array}{l}\text { Current particle } \\
\text { size } \\
\text { specifications }\end{array}$} \\
\hline & $\begin{array}{l}\text { Particle size and particle size } \\
\text { distribution, frit density }\end{array}$ & Insight into the flow rate & & \\
\hline \multirow[t]{2}{*}{$\begin{array}{l}\text { Frit slurry } \\
\text { rheology }\end{array}$} & Rheograms as a function of aging & $\begin{array}{l}\text { Transport of the frit } \\
\text { slurry }\end{array}$ & $\begin{array}{l}\text { Aging period } 1 \text { week, Holding } \\
\text { temperature } 50^{\circ} \mathrm{C} \text {. Compositions: } \\
60 \% \text { frit. } 40 \% \text { water: } 60 \% \text { frit. } \\
39 \% \text { water. } 1 \% \text { formic acid } \\
\end{array}$ & To be determined \\
\hline & $\begin{array}{l}\text { ICP and particle size as a function of } \\
\text { aging }\end{array}$ & $\begin{array}{l}\text { Insight int } \rho_{(1)} \text { the frit } \\
\text { dissolution }\end{array}$ & Sample slurry supernate & Not Applicable \\
\hline $\begin{array}{l}\text { Abrasiveness } \\
\text { testing }\end{array}$ & $\begin{array}{l}\text { Abrasiveness as a function of aging: } \\
\text { ASTM G } 75-89 \text { for Miller number and } \\
\text { slurry abrasiveness response (SAR) }\end{array}$ & $\begin{array}{l}\text { Pumping/pipe erosion } \\
\text { canister decontamination }\end{array}$ & $\begin{array}{l}\text { Aging period } 1 \text { week. Holding } \\
\text { temperature } 50^{\circ} \mathrm{C} \text { : Compositions: } \\
60 \% \text { frit. } 40 \% \text { water: } 60 \% \text { frit. } \\
39 \% \text { water. } 1 \% \text { formic acid }\end{array}$ & To be determined \\
\hline $\begin{array}{l}\text { Melter feed } \\
\text { rheology }\end{array}$ & Rheograms as a function of aging & Melter feed transport & To be determined & $\begin{array}{l}\text { Yield stress } 100 \\
\text { dyne/cm } \\
\text { Apparent } \\
\text { viscosity }(\mathrm{cp}) \text { : } \\
\text { at } 10 \mathrm{~s}^{-1} 700 \\
\text { at } 25 \mathrm{~s}^{-1} 300 \\
\text { at } 183 \mathrm{~s}^{-1} 70\end{array}$ \\
\hline Melting rate & \multicolumn{4}{|l|}{ Currently under development } \\
\hline it cooling & \multicolumn{4}{|l|}{ To be considered } \\
\hline
\end{tabular}

(a) Not necessary for specification.

(b) Covered under a separate cost account and investigation plan. 
so called single component constraints. These constraints represent the Timitations on the information obtained in developing the composition property models. The single component constraints are informational because the limits are based on performed experiments rather than a basic principle. Therefore, the range of the glasses should not be limited on this basis. For each of the 10 components, the single component constraints are expressed as:

$$
g_{i . L L} \leq g_{i} \leq g_{i . U L}
$$

where $\mathrm{LL}$ is the lower limit and $\mathrm{UL}$ is the upper limit. The limits for each component are given in Table 2.

TABLE 2. Upper and Lower Limits on Mass Fractions of Glass Components

Component, i

$\mathrm{SiO}_{2}$

$\mathrm{B}_{2} \mathrm{O}_{3}$

$\mathrm{Na}_{2} \mathrm{O}$

$\mathrm{Li}_{2} \mathrm{O}$

$\mathrm{CaO}$

MgO

$\mathrm{Fe}_{2} \mathrm{O}_{3}$

$\mathrm{Al}_{2} \mathrm{O}_{3}$

$\mathrm{ZrO}_{2}$

Other

$$
\text { Lower Limit-gi.LL }
$$

0.42

0.05

0.05

0.01

0

0

0.02

0

0

0.01
Upper Limit-gi,uL

0.57

0.20

0.20

0.07

0.10

0.08

0.15

0.17

0.13

0.10 
The critical solubility constraints limit the maximum value for the mass fraction of one or a combination of components (e.g. noble metals: $\mathrm{Rh}_{2} \mathrm{O}_{3}+$ $\mathrm{PdO}+\mathrm{Ru}_{2} \mathrm{O}_{3}$ ). These limits cover species not included among the nine species covered in the single component constraints. These are included within the tenth component "Other." These constraints are default constraints employed until the appropriate information regarding the true limits is available. The basis for the solubility constraints is rough empirical estimates and limited experimentation rather than fundamental principles or detailed investigation. These limits are of the form

$$
g_{10} \leq g_{10 . U L}
$$

and are given in Table 3.

The glass property constraints focus on the durability of the waste form, and the processing properties, viscosity, electrical conductivity, and liquidus temperature, which are crucial to making the glass. The durability

TABLE 3. Upper Limits on Critical Solubility Components

Solubility Component

\begin{tabular}{ll}
\multicolumn{1}{c}{ Solubility Component } & \multicolumn{1}{c}{$\mathrm{g}_{10, \mathrm{UL}}$} \\
\cline { 2 - 2 } $\mathrm{Cr}_{2} \mathrm{O}_{3}$ & 0.005 \\
$\mathrm{~F}$ & 0.017 \\
$\mathrm{P}_{2} \mathrm{O}_{5}$ & 0.01 \\
$\mathrm{SO}_{3}$ & 0.005 \\
Noble Metals $\left(\mathrm{Rh}_{2} \mathrm{O}_{3}+\mathrm{PdO}+\mathrm{Ru}_{2} \mathrm{O}_{3}\right)$ & 0.0025
\end{tabular}

Timit is the specification that cannot be compromised and is required for acceptability. The viscosity, electrical conductivity and liquidus temperature are technologically determined processing specifications and are required to ensure that the glass is manufacturable. For example, electrical conductivity is not a factor in a gas heated melter. Further, the electrical con- 
ductivity constraints are easily met given the alkali content of the anticipated wastes. The liquidus temperature constraint depends on the melter operating temperature and the residence time of the melt in the melter. Generally. viscosity, electrical conductivity and liquidus temperature depend. on melter design.

The empirical models for a property is typically of the form

$$
p=f(p)=\sum_{i=1}^{10} b_{i} g_{i}+\text { second order terms }
$$

where $b_{i}$ is the $i$-th component first order coefficient and 10 is the number of components considered in the study. A limited number of second order terms have been used to improve the models (Hrma and Piepe1. 1993). The limits on each of the properties for the current HWVP melter are given in Table 4.

Satisfying the described constraints permits the waste glass composition to be formulated. For a known waste composition, the composition of the frit is obtained by subtraction of the waste composition (plus recycle) from the

TABLE 4. Minimum and Maximum Glass Property Values

Property. Units

Viscosity at $1150^{\circ} \mathrm{C}$, Pa's

Electrical Conductivity at $1150^{\circ} . \mathrm{S} / \mathrm{m}$

Liquidus Temperature. ${ }^{\circ} \mathrm{C}$

Durability (release rate of boron by $P(T), g / m^{2}-7$ day

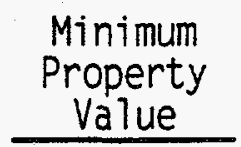

2

10

N/A

N/A

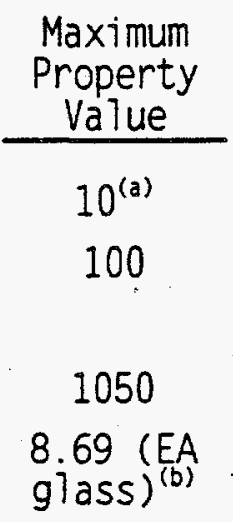

(a) Technological considerations point toward a viscosity range between 2 and $6 \mathrm{~Pa} \cdot \mathrm{s}$.

(b) EA glass: the reference standard, environmental assessment glass. 
glass composition. To verify that the requirements are met, the glass durability. viscosity at $1150^{\circ} \mathrm{C}$, electrical conductivity at $1150^{\circ} \mathrm{C}$ and liquidus temperature are measured.

The liquidus temperature constraint is required for processing since the current melter is sensitive to deposition of precipitated crystals. Previously. multicomponent constraints were used to quantify liquidus temperature and thus, crystallinity. Although these multicomponent constraints helped eliminate glasses with very low liquidus temperature, they are fruitless for actual frit formulation. To provide the basis of a liquidus temperature constraint. the Centre for Research in Computational Thermochemistry has developed thermodynamic software for Battelle Pacific Northwest Laboratory (PNL) (Pelton et a1. 1992). This software incorporates thermodynamic modeling to predict crystal7inity. liquid-7iquid immiscibility, and liquidus temperature $\left(T_{l}\right)$ of glasses covering the range of Hanford Waste Vitrification Plant (HWVP) glasses.

The program has been useful in predicting liquidus temperature and also equilibrium crystallinity as a function of glass temperature. With the first version of the software, the liquidus temperature has been predicted (with partial success) as a function of glass composition. Unfortunately, the current program does not consider some crystalline phases, such as spinels and clinopyroxene solid solutions, which have been observed in HWVP glasses. The formation of spinels was not considered because the software's database did not contain $\mathrm{Fe}^{2+}, \mathrm{Ni}$, and $\mathrm{Cr}$ information. As a result, solid solutions or crystals containing $\mathrm{Fe}^{2+}$. $\mathrm{Ni}$. or $\mathrm{Cr}$ are never predicted as the primary crystalline phase by the software.

A first order liquidus model (Chapter 11. Hrma and Piepel 1993) was also developed. This model was obtained from experimental data for waste glasses which precipitate spinel, clinopyroxene and zirconium phases. The liquidus temperature data were fitted to a first order model of the form:

$$
T_{1}=\sum_{i=1}^{10} b_{i} g_{i}
$$


The data for other crystalline phases was insufficient to create a model. This model is useful for predicting liquidus temperature of glasses with known primary phases for which model coefficients are available. This model cannot predict primary phases.

Some consideration has been given to increasing the waste loading while maintaining the primary waste glass constraints. Since increases in the waste loading are limited by these constraints and thus. the frit composition is similarly restricted, two waste optimization efforts will be reviewed. The first is a summary of the Optimize Waste Loading (OWL) approach for the Neutralized Current Acid Waste (NCAW). Secondly, an experimental effort was made based on a first order liquidus temperature model.

The previously described constraints were used for the OWL investigation. Fully employing the listed constraints resulted in a waste loading of $30.6 \%$ (recycle was not considered). Ignoring the lower limit on the $\mathrm{Fe}_{2} \mathrm{O}_{3}$ single component constraint (informational constraint) results in an increase in waste loading to $46.8 \%$ (recycle was not considered). Ignoring the upper limit on the "other" constraint. resulted in an increase of waste loading to 53.4\% (recycle was not considered). Lastly. using only viscosity. electrical conductivity and durability constraints the resultant waste loading was found to be $69.2 \%$ ( $58.3 \%$ including recycle). A relevant liquidus temperature constraint was not used. However, the results show that higher waste loading is obtainable especially when the primary constraints, excepting Tiquidus temperature, are heeded.

The glasses and frits used for the experimental investigation are shown in Table 5. These glasses do not satisfy the single component constraints. Experimentally, these glasses were produced from oxides carbonates and sulfates and melted in a platinum crucible for one hour at $1150^{\circ} \mathrm{C}$ using an electric resistance furnace. The crystallinity (see Figure 1 ) was evaluated for Canister Centerline Cooled (CCC) glasses and samples produced by an isothermal heat treatment. The isothermal treatment consisted of heating the samples for 30 minutes at $1150^{\circ} \mathrm{C}$ and then holding the samples for 24 hours at $1050^{\circ} \mathrm{C}$. The samples were then annealed for 2 hours at $500^{\circ} \mathrm{C}$. Each data point in Figure 1 represents an average of fourteen randomly-sampled 
measurements. As waste loading increased, the size of the error bars increased and was attributed to the agglomeration of spinels. The agglomeration resulted in sample heterogeneities. In addition, higher waste loading samples may have produced higher than actual volume fraction

TABLE 5. Glass and Frit Compositions of Increased Waste Loading Glasses

\begin{tabular}{|c|c|c|c|c|}
\hline \multirow[b]{2}{*}{ - } & \multicolumn{4}{|c|}{ Waste Loading (\%) } \\
\hline & 40 & 45 & 50 & 55 \\
\hline Component & \multicolumn{4}{|c|}{ Mass Fraction in Glass $g_{\mathfrak{i}}$} \\
\hline $\mathrm{SiO}_{2}$ & 0.4835 & 0.4524 & 0.4215 & 0.3906 \\
\hline $\mathrm{Na}_{2} \mathrm{O}$ & 0.1062 & 0.1194 & 0.1327 & 0.01460 \\
\hline $\mathrm{B}_{2} \mathrm{O}_{3}$ & 0.0426 & 0.0305 & 0.0183 & 0.0061 \\
\hline $\mathrm{Fe}_{2} \mathrm{O}_{3}$ & 0.1130 & 0.1272 & 0.1413 & 0.1554 \\
\hline $\mathrm{ZrO}_{2}$ & 0.0603 & 0.0678 & 0.0754 & 0.0829 \\
\hline $\mathrm{Li}_{2} \mathrm{O}$ & 0.0515 & 0.0443 & 0.0372 & 0.0301 \\
\hline $\mathrm{AT}_{2} \mathrm{O}_{3}$ & 0.0380 & 0.0428 & 0.0476 & 0.0523 \\
\hline $\mathrm{CaO}$ & 0.0088 & 0.0087 & 0.0085 & 0.0084 \\
\hline $\mathrm{MgO}$ & 0.0065 & 0.0060 & 0.0056 & 0.0051 \\
\hline \multirow[t]{2}{*}{ Others } & 0.0896 & 0.1008 & 0.1120 & 0.1232 \\
\hline & \multicolumn{4}{|c|}{ Mass Fraction in Frit $f_{i}$} \\
\hline Si02 & 0.8093 & 0.8289 & 0.8537 & 0.8858 \\
\hline $\mathrm{B}_{2} \mathrm{O}_{3}$ & 0.0773 & 0.0616 & 0.0416 & 0.0157 \\
\hline $\mathrm{Li}_{2} \mathrm{O}$ & 0.0934 . & 0.0895 & 0.0847 & 0.0785 \\
\hline $\mathrm{CaO}$ & 0.0100 & 0.0100 & 0.0100 & 0.0100 \\
\hline MgO & 0.0100 & 10.0100 & 10.0100 & 0.0100 \\
\hline
\end{tabular}


of crystals due to noble metal accumulation.

Examination of Figure 1 shows that the crystallinity of the CCC glasses increased (approximately) linearly with waste loading for the studied range. The isothermal samples showed a linear increase of crystallinity up to a waste loading of $50 \%$. The maximum average volume fraction of crystals observed was 0.058 at a waste loading of $55 \%$. The durability of these glasses were measured by the PCT method. All of the resultant durabilities were an order of magnitude more than the EA glass. In addition, these glasses were formulated

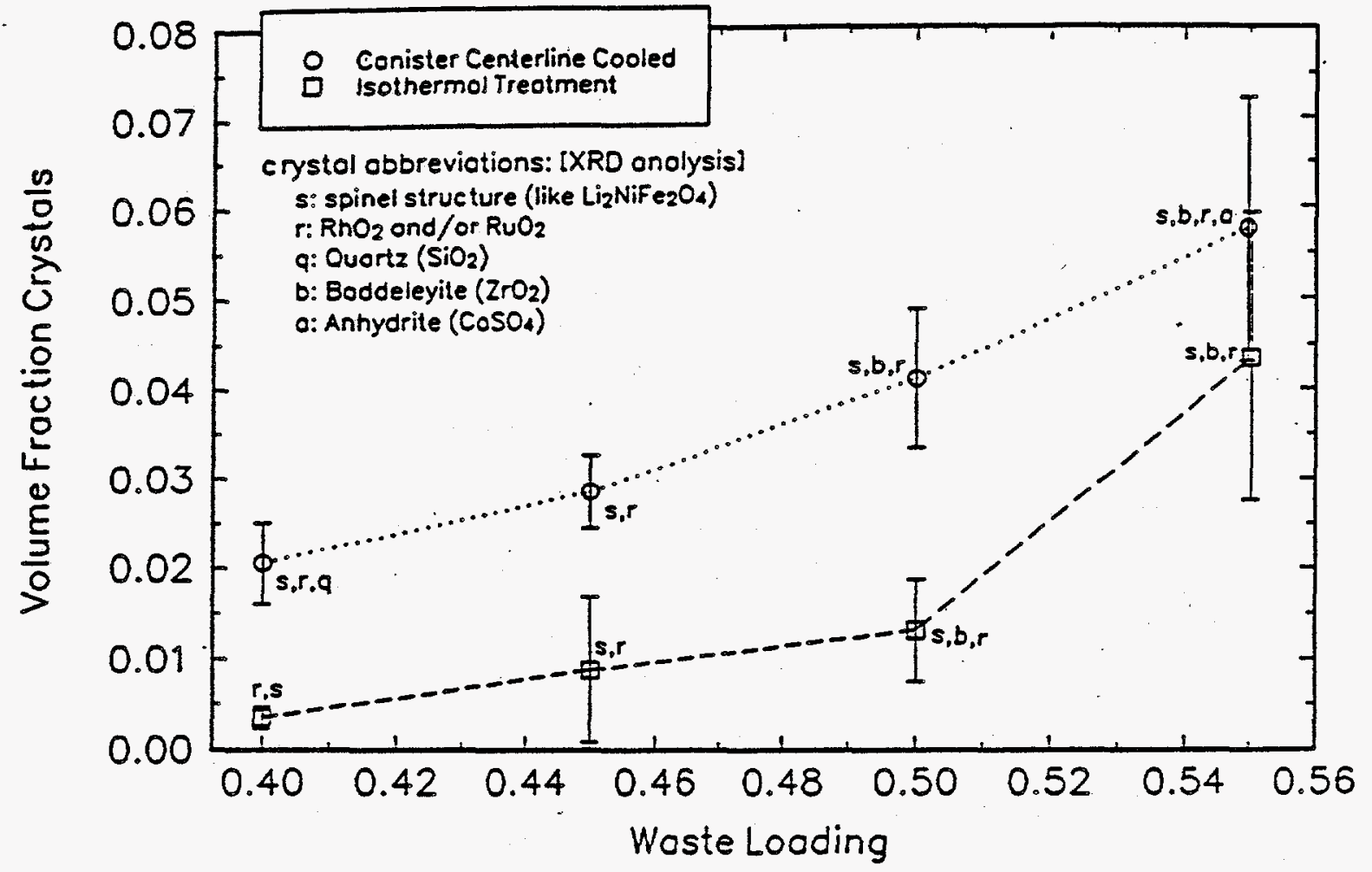

FIGURE 1. Volume Fraction of Crystalline Phases vs. Waste Loading 
with $\mathrm{MgO}$ and $\mathrm{CaO}$ as frit components. Preliminary results have shown that the same waste loadings are attainable with similar durabilities for frits without $\mathrm{MgO}$ and $\mathrm{CaO}$.

Based on the results of the OWL approach and the experimental effort. waste loading increases are possible. The computational effort utilized with OWL provides guidance for the calculation of frit and waste glass compositions. The experimental investigation showed that waste glasses can be successfully formulated outside the compositional limits of the current single component constraints. Increased waste loading will impose further restrictions on the frit composition. To successfully formulate waste glasses with increased waste content, the frit specification must consider the imposed constraints which will become more restrictive.

Crystallinity and liquidus temperature require experimental verification regardless of the predictive model or employed constraints. Optical microscopy, scanning electron microscopy (SEM). energy dispersive spectroscopy (EDS) and X-ray diffraction (XRD) are used to investigate crystallinity. This testing is accomplished on quenched glass and CCC glass. The quenched glass treatment represents the fastest cooling rate that glass in the canister wi 11 experience. The CCC test is representative of the slowest perceived cooling rate in the canister. The quenched glass and the CCC glass bracket the expected thermal history for the canisters. Since crystallinity is highly dependent on liquidus temperature and thermal history, these tests are required for glass processing and ultimately, frit specification.

Current programs are in progress at PNL addressing the above area as part of the Glass Envelope Definition cost account.

\subsection{REQUIREMENTS FOR THE CURRENT HWVP DESIGN}

The preceding discussion has focused on the glass processability and acceptability. To form the glasses. chemical additions to the wastes are required. Unless otherwise specified, these chemical additions will be made in the form of a frit. To insure plant operation, the frit must meet certain 
process criteria or alternative processing steps must be considered. For plant performance, there are six areas for specification: storage/handling properties, frit slurry rheology, frit slurry abrasivity, melter feed rheology. frit cooling, and melting rate. The performance areas in plant operation and requirements of the frit specification are discussed below.

\subsection{STORAGE/HANDLING}

Free flowing frit is needed to facilitate transport and batching. To quantify the storage and handling requirements of the frit, flow rate is measured. Flow rate is a function of particle size. particle size distribution. particle shape and moisture adsorption. For Defense Waste Processing Facility (DWPF) frit procurement, the moisture content was specified as $<0.1$ wt\% as determined by drying at $105^{\circ} \mathrm{C} \pm 5^{\circ} \mathrm{C}$ for at least 24 hours (Mertz 1993). The DWPF particle size distribution (Mertz 1993) was specified as:

$\geqslant 99$ wt\% through a U.S. Standard 80 mesh sieve with 98 wt\% considered acceptable.

$<10$ wt\% through a U.S. Standard 200 mesh sieve.

The particle size distribution was conducted in accordance with ASTM C-429. The specification also includes a statement that "the material must be free flowing." This statement also appears in Savannah River frit specifications (Carter 1988) but no qualifications are made. The flow rate can be quantified with the ASTM B13-90 test for Flow Rate of Metal Powders. A test of acceptable 202 frits can be made so that the upper and lower bounds on the flow rate are established.

The significant parameter to plant operation is flow rate. However. this is established by the particle size distribution and moisture content. If the moisture content and/or the size distribution are not varied. the 
limits estabiished by Westinghouse Savannah River Technology Center (WSTC) for particle size distribution and moisture content appear acceptable. The moisture content is controlled by hermetic seals on the frit containers. The result has been no known reports of flow problems of dry frit. If these conditions are not maintained, an examination of flow rate as a function of time and humidity is necessary.

\subsection{FRIT SLURRY RHEOLOGY REOUIREMENTS}

The current process flowsheet utilizes the frit in an aqueous slurry. The process frit slurry must be transported in the HWVP without any sedimentation or plugging. To insure that the frit can be transported in the HWVP. the frit slurry must be characterized in terms of rheology and sedimentation. Currentiy, there are no existing specifications that address this area.

Currentiy, the frit slurry is only described in terms of weight percent frit and formic acid (see Hanford Waste Vitrification Plant Technical Data Package (HWVP TDP)). The fluid mechanical requirements for the suspension have not been firmly established and thus. frit specification for frit slurry behavior is poorly defined. HWVP proposed limiting operating conditions required for this specification are:

- frit solids loading: 60 weight percent

- $\mathrm{PH}$ control: 1 weight percent formic acid

- applicable shear strain rates: To be determined (Graves 1993)

- temperature: $25-50^{\circ} \mathrm{C}$

- aging time: 1 week

- boiling time and temperature: None

With these conditions, the following tests can be accomplished:

1. shear stress versus shear strain rate for maximum aging time and the appropriate $\mathrm{pH}$ range: specifically, the frit slurry would be aged with agitation for 1 week at $50^{\circ} \mathrm{C}$.

2. ease of resuspension on the settled (24 hours) frit slurry for the conditions in 1. 
The acceptable results for these tests need to be determined. The technical basis for the proposed tests requires further development.

\subsection{FRIT SLURRY ABRASIVITY}

The frit slurry must perform canister decontamination and avoid erosion of the transport equipment. These areas require an abrasivity specification for the frit slurry which has not yet been defined.

The frit slurry behavior for canister decontamination has been described in terms slurry flow rate. slurry concentration. frit size (in the slurry), and particle shape (in the slurry) (Ward 1984: Graf and Rankin 1982). Slurry flow rate was controlled by the applied pressure and injected air to optimize the decontamination process. The influence of frit properties were not considered in terms of flow rate. Slurry concentration was treated similarly. As an estimate of particle shape's effect on blasting. Graf and Rankin compared dry "frit" to dry "beads". Beads refers to spherical frit. Shape factors or micrographs were not provided for the frit. Based on the comparison. frit blasting was improved with beads based on a better surface finish. less embedded frit. lower metal removal. increased equipment life, and a canister more resistant to corrosion. To require spheres as a frit shape specification would be quite costly. Furthermore, this work focused on the dry particle shape and not on the shape of the particle in the frit slurry. The particle shape in the slurry is relevant to the abrasivity and could be significantly different from the dry shape if a leachable frit were used. Alternative methods (Rankin 1982, and Charlesworth 1986) for decontamination of the waste glass canisters have been examined. These methods could be reviewed prior to limiting a frit based on a decontamination consideration.

The frit particle size was shown to have a significant effect on blasting efficiency (Ward 1984). Frit sizes between -80 and +325 mesh were compared for their effect on blasting efficiency. Frit sizes between -80 and +140 were more efficient than sizes between -140 and +325 . However, this was not described as a limiting variable for the decontamination process. Fur- 
ther, the desirable particle size range for canister decontamination are satisfied within the procurement specifications ( -80 and +200 mesh).

The frit slurry must not erode the exposed piping and pumping equipment in the HWVP. The frit slurry properties related to wear include frit geometry. particle size, and solids concentration. ${ }^{(a)}$ Frit beads were shown to be less abrasive (based on metal wear rates) compared to angular frit. Particle sizes from -80 to +325 mesh were compared. Increases in particle size resulted in frit slurries with higher abrasivity (based on metal wear rates). The tests of solids concentration on metal wear rates were inconclusive. These results do not appear to be limiting in terms of the frit specification.

Canister decontamination and equipment erosion should be quantified by the frit slurry abrasivity rather than individual specifications on the factors which influence the abrasivity. It must be realized that canister decontamination and equipment erosion require diametrically opposed responses from the frit slurry. First, the acceptable wear rates and decontamination parameters must be established and linked to a frit slurry abrasivity specification. Then, the frit slurry should be tested for abrasivity (ASTM G 75-89) while considering the proposed limiting HWVP operating conditions:

- frit solids loading: 60 weight percent

- $\mathrm{pH}$ control: 1 weight percent formic acid

- temperature: $25-50^{\circ} \mathrm{C}$

- aging time: 1 week.

\subsection{MELTER FEED REQUIREMENTS}

Melter feed rheology provides for the delivery of the waste and the frit to the melter. Tentative melter feed rheology specifications (at $25{ }^{\circ} \mathrm{C}$ ) listed the nominal yield stress is $100 \mathrm{dyne} / \mathrm{cm}^{2}$ and the following apparent viscosities: at $10 \mathrm{~s}^{-1} \quad 700 \mathrm{cp}$

(a) Graf. P. L. 1984. Memo (DPST-83-204), from P. L. Graf to H. D. Martin, "Metal Wear Rates in Sludge/Frit Slurries: Interim Report." 
$\begin{array}{ll}\text { at } 25 \mathrm{~s}^{-1} & 300 \mathrm{cp} \\ \text { at } 183 \mathrm{~s}^{-1} & 70 \mathrm{cp}\end{array}$

This is based on the HWVP TOP. These specifications are written for Bingham behavior. No thought has been developed for melter feed that does not fit the Bingham model. Melter feed rheology must be described in fluid mechanical terms so that a purposeful specification can be applied to melter feed rheology and the frit.

Despite the lack of a thorough description of the melter feed rheology. the influences of the frit can be described. First, the unleached frit particles behave as hard equivalent spheres and can be treated as such in rheological and fluid mechanical terms. However, some frit compositions are subject to leaching. The relationship between the leaching of frit and rheology has not been clearly established. To specify frit for melter feed rheology, a test which mimics the frit leaching in the melter feed is needed.

To establish the frit behavior for the melter feed rheology the $\mathrm{pH}$ is monitored and chemical analysis of the melter feed supernatant is performed over a 4 week period. Durability testing performed on the frit provides insight into the frit changes that occur in the melter feed. These tests are not required as part of the frit specification. These tests may provide information relevant to the required testing conditions.

The results of the PCT tests on four frits (see Table 6) are shown in Figure 2. Figure 2 shows that frits FY93 and HW39 dissolve in near congruent amounts with respect to boron, sodium, and lithium. The FY91 frit showed a much higher dissolved fraction, with boron and lithium fractions nearly congruent. The 202 frit did not dissolve congruently. The boron of the 202 dissolves more readily than the lithium and sodium components. For all of the frits, the silica shows a much lower concentration in solution compared with the other frit constituents.

The normalized release data from the MCC-1 tests are listed. in Table 7 for the frits HW39. FY 91 and 202. Obvious7y, the releases for frits FY 91 were much higher than the other frits. This behavior is similar to the PCT results. The Materials Characterization Center static leach test (MCC-1) release data showed that the HW39 frit was less durable compared to the 202 
frit. These results were opposite to the PCT results. However, melter feed experience has shown that the HW39 and 202 frits perform adequately with respect to rheology. Thus, the differences in the PCT and MCC-1 tests may not be important as applied to the frit specification for rheological purposes.

The $\mathrm{pH}$ as a function of aging time was measured as part of the melter

Table 6. Frit Compositions (in weight percent)

\begin{tabular}{|c|c|c|c|c|c|}
\hline Name & $\mathrm{SiO}_{2}$ & $\mathrm{~B}_{2} \mathrm{O}_{3}$ & $\mathrm{Li}_{2} \mathrm{O}$ & $\mathrm{Na}_{2} \mathrm{O}$ & $\mathrm{MgO}$ \\
\hline 202 & 77 & 8 & 7 & 6 & 2 \\
\hline FY91 & 72.3 & 20.4 & 7.3 & & \\
\hline HW39 & 70 & 14 & 5 & 9 & 1 \\
\hline FY93 & 74 & 12 & 6 & 6 & 1 \\
\hline
\end{tabular}

Table 7. MCC-1 Results for HW39, FY91 and 202 Frits

\begin{tabular}{|c|c|c|c|c|}
\hline \multicolumn{2}{|l|}{ Frit } & HW39 & FY 91 & 202 \\
\hline Chemical & Element & \multicolumn{3}{|c|}{ Normalized Mass Release $(\mathrm{g} / \mathrm{m} 2)$} \\
\hline $\mathrm{SiO2}$ & Si & 78.648 & 266.133 & 34.688 \\
\hline$B 203$ & $B$ & 99.908 & 2201.275 & 35.169 \\
\hline Li02 & $\mathrm{Li}$ & 98.925 & 2448.486 & 32.258 \\
\hline $\mathrm{NaO2}$ & $\mathrm{Na}$ & 98.083 & & 35.939 \\
\hline
\end{tabular}




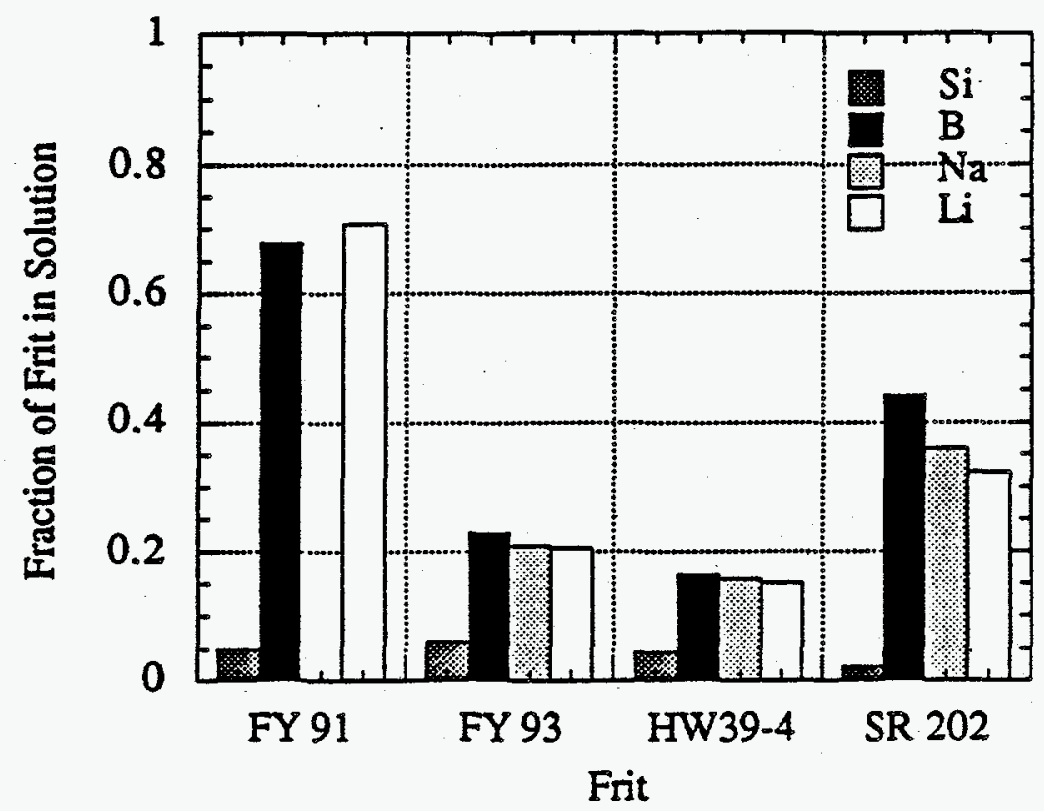

FIGURE 2a. Molar Fraction of Frit Component in Solution After 7-Day PCT

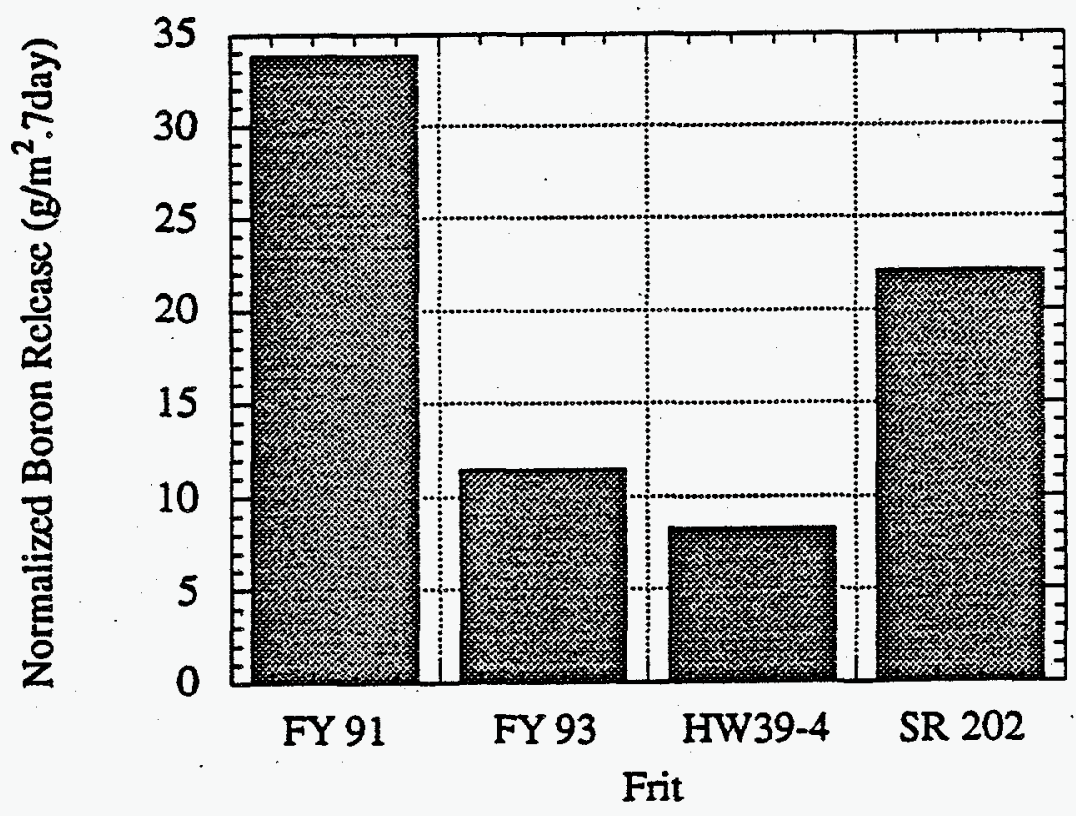

FIGURE 2b. Normalized Boron Release from Frit After 7-Day PCT

feed rheology experiments. Melter feed consists of formated neutralized current acid waste (FNCAW) (Smith, 1991), recycle and frit. The melter feed 
was formulated at a concentration of $500 \mathrm{~g} \mathrm{TO} / \mathrm{L}$ and boiled for two hours. Then, the samples were aged for four weeks under constant agitation. Three frit types. HW39, 202 and FY91 were measured and the results are shown in Figure 3.

FNCAW (before frit addition) typically has a pH between 6.5 and 7 . From Figure 3, the effects of the different frit or melter feed $\mathrm{pH}$ are observed. At time 0 (after boiling), the FY91 melter feed suspension increased to pH 9.1. The pH remained between 9 and 9.7 during the aging period. The initial rapid increase in $\mathrm{pH}$ reflects a substantial leaching during boiling of the FY91 frit. For the HW39 and 202 melter feeds, the $\mathrm{pH}$ increase proceeded at a slower rate. The $\mathrm{pH}$ after boiling was between 6.5 and 7.0 which shows that leaching did not occur during boiling. After four weeks, the $\mathrm{pH}$ of the HW39 and the 202 melter feeds was between 8 and 9. Based on the pH results, the HW39 and 202 frits in melter feed showed less leaching at a slower rate compared to the FY91 frit.

Examination of the ICP results of the melter feed a fter four weeks of aging for the cations $\mathrm{Li}, \mathrm{B}$ and $\mathrm{Si}$, in the melter feed supernatant will provide insight into frit leaching. The lithium and boron in the supernatant are attributed entirely to frit leaching since these cations are minor constituents of the waste. Silica gel networks can alter rheology significantly and therefore, the Si cation is reported. The durability results for FY91. HW39 and 202 frits are provided in Table 8.

The FY91 frit showed significantly higher leaching of the Li compared to the HW39 and 202 frits. Since Si was not detected in the supernatant of any of the melter feeds, the frit specification would not benefit by including a $S i$ requirement for melter feed rheology. While the Li depicts the leaching of the frit in the melter feed rheology testing, a correlation has not been made in laboratory experiments for frit leaching and the rheological behavior. Hence, this test cannot currently be used to specify frit. 


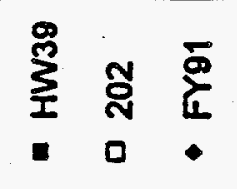

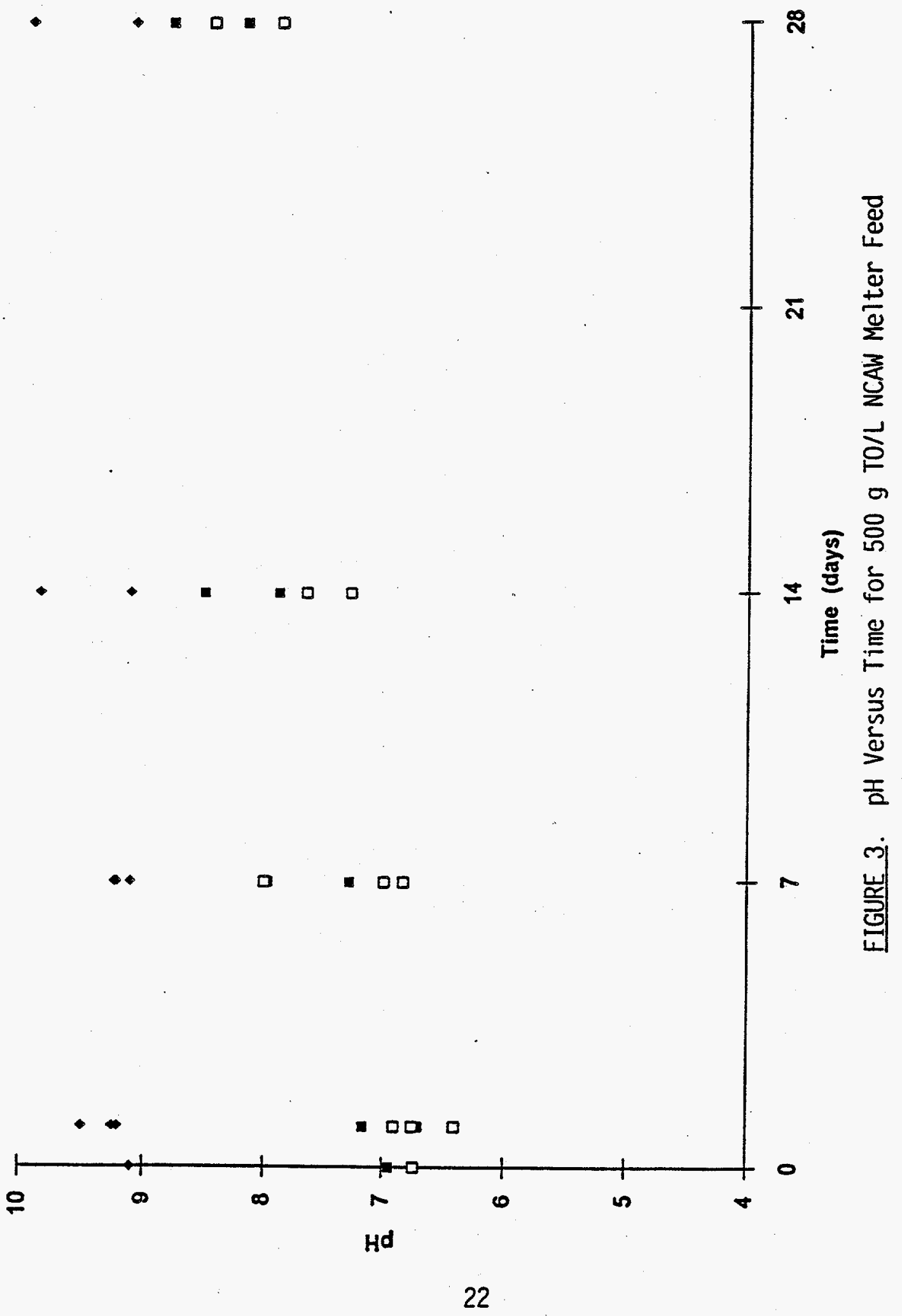


A comparison of the PCT. MCC-1 and melter feed rheology results can be made for frit specification. The melter feed rheology test is not sensitive to Si dissolution. Furthermore. the chemistry of the melter feed is inherent ly complex. Since Si may cause rheologically important effects and the feed chemistry may obscure frit effects. ICP results from melter feed rheology testing are not recommended for isolating rheological effects related to frit composition for the frit specification. The MCC-1 and PCT experiments produced results similar to each other. The results showed that the durability of the FY91 frit was much lower than either the 202 or HW39 frits. The HW39 frit showed a higher durability for the PCT test and a lower durability in the MCC-1 test when compared to the 202 frit. It is not clear that this difference is significant in terms of melter feed performance and

TABLE 8. Percent Cation Leached from Frit after Four Weeks of Aging

\begin{tabular}{|c|c|c|c|}
\hline Melter Feed Frit & $\underline{\mathrm{Li}}$ & $\underline{B}$ & $\underline{\mathrm{Si}}$ \\
\hline FY91 & 86 & 16 & 0.00 \\
\hline HW39 & 29 & 10 & 0.00 \\
\hline 202 & 34 & 15 & 0.00 \\
\hline
\end{tabular}

therefore. the frit specification. Since the PCT test requires only 7 days. it should be used for the specification of frit durability as it relates to aqueous processing. Future developments may permit the influence of frit on melter feed rheology to be determined in terms of frit durability.

Technical development and review of available data are required to establish rheology testing conditions and acceptance criteria.

\subsection{FRIT COOLING}

During frit manufacturing, a molten glass is cooled, and a frit is produced. The quenching is accomplished by pouring the molten glass into. water. The rate of temperature change during frit manufacturing affects phase separation. The influence of phase separation on the frit properties has not been previously considered. Phase separation may affect the nature of the 
frit-water interactions which could affect melter feed and frit slurry transport and canister decontamination. Thus, a specification for cooling rate may be required, and further study is warranted to determine the need and form the specification may take.

\subsection{MELTING RATE}

The crucial variables for controlling the melting rate of high level nuclear waste have not been identified. The frit composition will define a viscosity versus temperature profile. Hence, sintering of the dry feed. formation of bubbles in the sintered feed, to some extent, are affected by frit composition. The other factors of importance have been listed by Kim (1993). An indicative test and testing conditions need to be developed for an appropriate specification. This effort is planned as part of the proposed melt rate study (Kim 1993).

\subsection{HIERARCHY}

The individual frit specifications should be prioritized to reflect the importance of each based on waste form acceptability and processability. The glass durability specification is the single most important specification and cannot be compromised. To make the vitrification effort more economical and minimize the volume of waste glass the waste loading should be maximized by choosing the frit according to the OWL approach. Naturally, the waste loading is limited by the durability of the resultant waste glass. Further, the waste loading is also limited by manufacturing constraints such as glass viscosity; electrical conductivity and liquidus temperature. The waste glass must be manufacturable. To ensure a manufacturable waste glass, an appropriate frit must be chosen according to technological process specifications.

The preceding specifications are entrenched in the property composition models. The subsequent specifications are related to processability of the frit within the HWVP and are secondary to the glass durability and manufacturing constraints. These specifications include storage/handling. frit slurry, melter feed rheology and melting rate. For some of these specifications, the processability criteria has not been determined and/or the 
appropriate test(s) have not been established. In addition, these areas are related to particular aspects of processing and the required behavior can be attained by means other than changes in frit composition. For example, frit flow rate can be modified by changes in the particle size distribution. Since these specifications are not well defined currently. no further prioritization will be attempted.

\subsection{SCHEDULE AND COST}

The melter feed rheology scope of work is estimated at $\$ 200 \mathrm{~K}$. This work would include an initial frit property composition model. It is probable that both of these tasks could be completed by September 1994. There are several areas of specification which require further definition. Without this definition. it is not possible to describe a schedule and cost for the work. 


\subsection{REFERENCES}

ASTM C-429-82. 1982. Standard Test Method for Sieve Analysis of Run Materials for Glass Manufacture.

Carter. J. T. 1988. "Frit 202 Specification." DPST-88-341 rev 1. Savannah River Laboratory. Aiken. SC.

Graf, P. L., and W. N. Rankin. August 1982. "Potter's Industries Tests of Spherical Frit." DPST-84-646.

Graves, R. and R. McKay. 1993. "Frit Slurry Testing Addendum to Test Plan for SIPT Hanford Waste Vitrification Program." PHTD-C93-04.14Y.

Hanford Waste Vitrification Technical Data Package WHC-SD-HWV-DP-001.

Hrma, P. R. and G. F. Piepel. 1992. Property/Composition Relationships for Hanford Waste Vitrification Plant Glasses-Preliminary Results Through CVS-II

Phase 2. PHTD-92-03.01/K897. Pacific Northwest Laboratory, Richland. Washington.

Kim, D. S. and P. R. Hrma 1993. "PNL HWVP. Technology Development Project Melting Rate Test Approach." PHTD-C93-03.01G, Pacific Northwest Laboratory, Richland. Washington.

Mertz, M. L. 1993. "Procurement Specification for DWPF Frit 202 (U)." X-SPP-S-00004 rev 2.

Pelton. A. D.. P. Wu, and G. Eriksson. November 1992. "Development of Models and Software for Liquidus Temperatures of Glasses of HWVP Products." (final report). Contract \#157998-A-F1. Centre for Research in Computational Thermochemistry submitted to Battelle. Pacific Northwest Laboratory. Richland. Washington.

Smith. R. A. 1991. "Revision of Pretreated Neutralized Current Acid Waste Composition for FY 1991 Pilot Testing-Errata Correction". Letter to J. M. Creer. \#9150151

Ward. C. R. 1984. "Selection and Development of Air Injected Frit Slurry Blasting for Decontamination of DWPF Canisters." DP1692. 